\title{
Varoluşa Ait Bir Gerçekliğin Betimleyicisi Olarak "Saçma” ve Amerikan Sinemasında İfade Biçimleri
}

\author{
ÇAĞDAŞ EMRAH ÇAĞLIYAN* \\ c_e_cagliyan@hotmail.com
}

\begin{abstract}
Özet: İnsan varoluşunun tüm dönemlerindeki başlıca sorunlardan biri yaşamanın anlamlı bir eylem olup olmadiğıdır. Bir yandan, günlük yaşamda sürekli karşılaşılan olguların sağlam bir temelden yoksunluğu ve her gün yinelenen rutin eylemler, öte yandan ölümün, insan varlığını kendi geçici mahiyetiyle yüzleştiren katı gerçekliği, kişileri kendi varoluşlarına ilişkin sorgulamaya itmektedir. Bireyin, oluş dünyasına haklı bir gerekçe arama çabasının, olguların olumsuz yanıtıyla karşılaşması, Albert Camus'nün "saçma" kavramının temelini oluşturmaktadır. Saçma kavramı, öncelikle yeryüzünün nedensiz doğasını, insanın anlamsizliklar evreninde usa uygun bir anlam arama çabasını vurgulamaktadır. Bu anlam arayışı, ölümün dışındaki her türlü gerçekliğin yavan bulunuşunu getirmekte, böylece genel bir insanlık durumu betimlemektedir. Dolayısıyla, eski çağlardan beri, ortaya çıkmış her türlü anlatıda, saçma kavrami, temel motiflerden biri olarak yer almaktadır. Bu çalışmada Albert Camus ve Friedrich Nietzsche gibi düşünürlerin, saçma bağlamındaki görüşleri merkeze alınarak, Amerikan sinemasına ait, amaca yönelik örneklem yöntemiyle seçilmiş, beş film örneği, niteliksel analize tabi tutulmuştur. Anlamsızliğın neden olduğu bunalımı aşma biçimleri ve saçmanın bilincinin yol açtığı nihai yazgı söz konusu filmler aracılı̆̆ıyla irdelenmiştir.
\end{abstract}

Anahtar Kelimeler: Saçma, Rastlantı, Yazgı, Albert Camus, Friedrich Nietzsche, Amerikan Sinemast.

\section{Giriş}

Bilinçli bir varlık haline geldiği andan itibaren, insanın karşılaşabileceği en önemli soru; sürdürdüğü yaşamın belirgin bir anlamının olup olmadığıdır. İnsanın, bir yandan ölümün katı gerçekliğine tanık olup kendi varlığının geçiciliğiyle yüzleşmesi, diğer yandan günlük deneyimlerinin rutin bir şekilde yinelenen eylemlerden ibaret olması bu anlam gereksinimi arttırır. Ancak insan zihninin anlam arayışı, sıklıkla olgular dünyasının mantık dışı yanıtlarıyla karşılaşır. Albert Camus'nün saçma (uyumsuz, absürd) kavramı, içinde bulunduğu sınırlı yaşam koşullarının bilincine varmış kişilerin, daha derin bir anlam arayışını dile getiren çağrılarına, her gün karşılarında buldukları olguların tümüyle sessiz kalışını ifade etmektedir. Bu noktada, insanlar, gözlemlediği yaşantıların ve olayların hiçbir haklı nedene dayanmayan şekilde süregeldiğine, yeryüzünün adil ve mantıksal her türlü temelden yoksun olduğuna tanık olmaktadır. Bu nedenle, saçmayı algılayan, saçma duygusuna sahip bu kişiler, kendilerini kuşatan yeryüzünde, harekete geçerken güvenebilecekleri sağlam

\footnotetext{
* Arş. Gör. Dr., Başkent Üniversitesi, Radyo Televizyon Sinema Bölümü.
} 
bir zeminin olmadığına, yalnızca kaos, kargaşa ve rastlantılarla örülü bir uzamda tutsak kılındıklarına kanaat getirmektedir.

Saçma kavramına edebi ve düşünsel yazınında merkezi bir konum veren Camus, bu kavramı açıklamak için mitolojik bir figürden, Sisifos'tan yararlanmıştır. Sisifos, yaşamaya duyduğu güçlü arzu nedeniyle Hades’i alt edip tanrıları aşağıladığı için sırtındaki kayayı Olympos Dağı'nın tepesine çıkarma cezasına çarptırılır. Sisifos'un yazgısı, hiçbir sonuca ulaştıramadığı bu eylemi sonsuza dek yinelemek haline dönüşür. Dolayısıyla, Sisifos'un yazgısı, amacına erişmek üzereyken sürekli düş kırıklığına uğramaktır (Homeros 2000: 200).

Sisifos'un yazgısına trajik bir özellik kazandıran ve onu saçma kavramında bir dayanak noktası haline getiren özelliği ise, yalnızca sonsuz acıya göğüs germekle yetinmeyip eylemlerinin bir sonuca varmaksızın yineleneceğinin farkında olması, içinde bulunduğu durumun "saçma” lığının bilincine varmasıdır. Camus'nün yorumuyla Sisifos; "Tutkularıyla olduğu kadar sıkıntısıyla da uyumsuzdur. Tanrıları hor görmesi, ölüme kin duyması, yaşam tutkusu, tüm varlığı hiçbir şeyi bitirmemeye yönelttiği bu anlatılmaz işkenceye malolur. Yeryüzünün tutkuları için ödenmesi gereken ücrettir bu" (Camus 2011: 138). Ancak her ne kadar, içinde bulunduğu durumun umutsuzluğunu kavramış olsa da, Camus'ye göre, Sisifos "bu korkunç işkenceden" haz duymakta, "bilincinin verdiği sevinçle bir çeşit mutluluğa, umutsuzluğun mutluluğuna" erişmektedir (Akt. Erhat 2006: 272).

Dolayısıyla, insan varoluşuna ait ağır bir yükü sırtlayıp sonsuza dek taşımaktan yılmayan Sisifos'un açığa vurduğu durum, meydan okuyup saçmalığın bilincine varmakla gerçekleştirilen yazgının, kişiye pişmanlık vermemesi gerektiğidir. Çünkü somut hiçbir kazanım elde edemeyeceği eylemlerini, "Sisifos'un kayası" gibi kendi nesnesi kılan uyumsuz insan, çekmekle yükümlü olduğu ebedi sıkıntıya ilişkin düşündüğü zaman, kendisi üzerinde egemenlik kuran tüm “putlar” 1 üstesinden gelmektedir. İnsan, kendi yaşamının amaçsız ve anlamsız doğasıyla kuşatılmış olsa da, onurunun ve kişiliğinin önüne koyduğu tek yolun, kendisini çevreleyen katı gerçekliğin dayattığı zorunlu yükü taşımak olduğunun bilgisine erişmektedir ${ }^{1}$.

Söz konusu sorun, tüm insan varoluşuna genellenebilir olduğu için, insan varlığının içinde bulunduğu çağa özgü olarak, ortaya koyduğu yaratımlara önemli ölçüde yön verebilmektedir. Dolayısıyla, Antik Yunan tragedyasından, 19. yüzyıl romanına ve günümüz sinemasına kadar, varoluşun nedensizliğinin yarattığı krizden kaynaklanan saçma duygusunun izlerine rastlamak olanaklıdır. İnsan varoluşuna ait zaman ve uzamla sinırlanamayan bu olgu, Dünya sinemasına yön verme gayesiyle hareket

1 Başkaldıran İnsan kitabında Camus, Tanrı’yı ve ahlaksal putları yadsımanın ardından insanın "yalnız ve efendisiz” kaldığını belirtmektedir (1975: 83). Buna göre, Tanrı’ya ve öte dünyaya inancını yitirdikten sonra ise, insan, tanıklık ettiği her şeyden sorumlu olacaktır. Bu doğrultuda, Sisifos’un sırtladığı kayayı, aşkın gerçekliği yadsıyan "başkaldıran insan”ın taşıdığı sorumluluğun yüküyle bir tutmak olanaklıdır. Dolayısıyla, nedensiz ve anlamsız bulunan yeryüzünde anlamı yaratabilecek tek güç tekil varlık olarak insandır. Ancak, gerek Camus’nün gerekse Nietzsche’nin görüşleriyle uyumlu olarak, bu anlamın belirlenmesinde keyfi bir nitelik yoktur; bireysel bilinç uyarınca benimsenen bir yasanın varlığı söz konusudur. İnsan, kendisini varoluşunun mahiyetine yönelik sorgulamadan, tasalardan uzak tutan, çevresiyle uyumlu yaşamasını kolaylaştıran aşkın varlığı yadsıyarak tümel bir sorumlulukla yüzleştiğine göre; bu yasanın sorumluluktan, tekil olanın tümel olandan ayrılamayacağı açıktır. 
eden ve bu nedenle olabildiğince evrensel konulara yer veren Amerikan sinemasının önemli örneklerinde de ele alınmış ve saçmanın bilincini taşıyan kişiler genellikle zihinsel farklılıkları öne çıkarılacak biçimde işlenmiştir. Film örneklerinde saçma düşüncesinin ortaya koyulma biçimlerini çözümleyebilmek için öncelikle bu kavramın art alanındaki düşünsel temelleri irdelemek gerekmektedir.

\section{Saçma Kavramı ve Düşünsel Tamamlayıcıları}

Çağımızın insanının yaşamından duyduğu rahatsızlığın belki de en büyük nedeni, günlük deneyimlerin düşünsel çabadan yoksun, bilinçsiz sayılabilecek rutinlikte ilerlemesi, içinden çıkılmaz bir döngü niteliğine bürünmesidir. Theodor Adorno ve Max Horkheimer, bu durumu, günlük yaşamın her katmanında ideolojik olarak kendini dayatan makineleşmeye, "seri üretim odaklı" düşünsel yapıya dikkat çekerek açıklar: "Seri üretimin kültürü ve sayısız faili aracılığıyla norm haline getirilen davranış biçimleri bireye yegâne doğal, saygıdeğer, mantıklı davranış biçimi olarak dayatılır. $O$ kendini bundan böyle şey olarak, istatistiksel bir öğe, başarı ya da başarısızlık olarak tanımlayabilir” (2010: 49-50). Buna göre, bir anlamda, insanın kendi kurduğu işleyim düzeninde, gittikçe düzeneğe ait bir parça, bir dişli konumuna indirgenmesi söz konusudur.

İnsanın kendi doğasıyla arasına mesafe koyan, onu diğerleriyle aynı kalıba sokan "nesneleşme" ve "otomatlığa indirgenme" durumu, yeryüzünde anlam arayışıyla ilgili çabaların boşa çıkacağı düşüncesini doğurmuştur. Albert Camus, anlamsızlık duygusunun en büyük tetikleyicilerinin, kişilerin "şeyleşme"si, edimlerin mekanikleşmesi olgusu olduğunu vurgulamıştır. Camus’ye göre: “Anlamsızlı̆̆ın neredeyse her zaman olguların ve varlıkların makineleşen yüzüyle -sıklıkla da alışkanlıkla- özdeşleştiği saptanır. Her şey alışkanlığa dönüşüyorsa, önemli düşüncelerin ve önemli eylemlerin anlamsıza dönüşeceği kesin demektir” (2003b: 77).

Koşulların kendisine dayattığ 1 yinelemeye mahkûm olan ve gittikçe kendi doğasına yabancılaşan insan, yeryüzünün derin bilgisine erişmeye, onu kendince içselleştirmeye çalışırken, genellikle olguların usdışı yanıtlarıyla karşılaşmaktadır. Duyarlı bir bilincin olgusallığa özgü bu anlamsızlıkla uyumsuzluk sergilemesi, saçma duygusunu ortaya çıkarmaktadır. Ancak bu uyumsuzluk, saçma duygusunu taşıyan kişi tarafından, hayıflanma şeklinde hissedilmez ve örtbas edilmeye çalışılmaz. Tersine, Frederick Copleston'un belirttiği üzere, "saçmanın bilincine varmış insan”, evrene ilişkin algısını çarpıtabilecek, gerçekliği örten her türlü "perde” yi yadsımaktadır: "Açık görüşlü insana dünya herhangi bir belirli amaç ya da anlamdan yoksun görünür. Dünya ussal değildir. Saçmanın duygusu bu nedenle doğar. (...) Dünya kendinden saçma değildir: Yalnızca vardır. Saçma, insanın yakarışı ve dünyanın usdışı sessizliği arasındaki bu karşılaşmadan doğar” (2010: 62). Dolayısıyla, "saçmanın insanı”, dünyayı daha yaşanılır kılmak için ona sahip olmadığı anlamlar yüklemeye kalkışmaksızın, öncelikle onu olduğu gibi kabul etmektedir. Yani, saçma düşüncesi, tüm usdışılığına ve rastlantısallığına karşın yeryüzünü olumlamaktadır. Bu rastlantısal dünyayı daha anlaşılır kılmak için “mutlak gerçeklikler”e gereksinim duymamakta, önündeki olgusallıkla yetinmektedir. 
Dolayısıyla, saçma duygusunu taşıyan kişi gerçekliği uzlaşımsal perdelerle kapatmaz; Albert Camus'nün Tersi ve Yüzü kitabında verdiği örnekten hareketle, idam edilecek bir mahkûmda, "topluma ödenen borcu" değil, yalnızca "kesilecek olan kafayı" görür (2010: 48). Dolayısıyla saçmanın bilincini taşımaya başladıktan sonra kişi, tanıklık ettiği olay ve olguların çoğunluk tarafından kabul edilen anlamını yok saymakta, bu olay ve olguların tüm somutluğuyla kendini dışavuran "anlamsızlı̆̆ı"yla ilgilenir².

Bu noktada, deneyimlenen olguların değerini düşüren ve anlamsızlığı egemen kılan çoğunluğa ait uzlaşımların, genellikle doğal olanı dışladığı görülmektedir. Tarihsel süreçte insan, bir yandan görece özgürlüğe kavuşmuş, öte yandan çevresel koşulların belirleyiciliğine dayanamayıp bilincinin gittikçe tutsaklaşmasına kayıtsız kalmıştır. Uygarlık geliştikçe, insan, doğadan kopmaya başlamış, kendi doğasını kontrol altında tutmaya çalışmış, kendisine çizilen sınırların dışına çıkmamaya özen göstermiştir. Nietzsche’nin vurguladığı gibi, insan doğasının kontrol altına alınması, uzlaşımsal ahlak yasalarının işleyişe sokulmasıyla mümkün olmaktadır. Topluca kabul edilmiş olan buyurgan ahlak yasalarının işlevi ise, insanın doğal yetilerini, tutkularını ve her türlü gizilgücünü kazıyıp sıradanlaştırmak, bireysel yaşam deneyimini iğdiş etmektir. Nietzsche’nin ifadesiyle; "Ahlaktaki her doğalcılık, (...) yaşamın herhangi bir buyruğu belirli bir 'yapmalı' ve 'yapmamalı' yasasıla gerekçelenir, böylelikle yaşamın yolunun önündeki herhangi bir engel ve düşmanlık bertaraf edilir. Doğa karşıtı ahlak, yani şimdiye dek öğretilmiş ahlak, tam tersine, tam da yaşam içgüdülerine karşı yönelir” (Nietzsche, 2005: 36). Böylece, "doğal olan”, kutsal olana karşıt biçimde konumlandırılmış, cezalandırılmaya layık bulunmaya başlanmış ve sonunda insanın gerçek dünyadan kopuşuna zemin hazırlanmıştır. Dünyanın nedensizliğinin, "adaletsiz"liğinin yarattığı bunalım, insanı sonunda "gerçek dünya”yı, yani içsel ve dışsal tüm yönleriyle doğayı reddetmeye, lanetlemeye götürmüştür: "Doğa kavramı 'tanrı'nın karşıt kavramı olarak ikame edilince, "doğal” sözcüğ̈̈ "günahkâr" anlamına gelmek zorundaydı, bütün bu uydurmalar dünyası (...) gerçek karşısında derin bir hoşnutsuzluğun dile gelişiydi” (Nietzsche, 2008: 22). Bir anlamda, kişiler, her an karşı karşıya oldukları olguların anlamsızlığıyla yüzleşmeye dayanamadığı için, bu olgulara uzlaşımsal bir anlam yüklemiş, sonunda işi, bu anlam uğruna gerçeğin kendisini, doğayı yadsımaya götürmüştür.

İnsan, "lanetlediği” doğayı yadsıyıp benimsediği aşkın "değerler” ile kendisini avutmaya çalışsa da, sonunda anlamsızlık duygusunun içine düşmekten kurtulamaz. Horkheimer'e göre, anlamsızlığa neden olan yabancılaşma sürecinin başlangıcında yer alan en belirgin etkenlerden biri, doğanın insan tarafından denetim altına alınmış olmasıdır (2010: 120). Doğa üzerinde egemenlik kurmayı, insan üzerinde egemenlik kurma izlemiştir; bireyler dışlarındaki doğanın "köleleştirilmesi”ne katkıda bulunmalarının yanında, bu "boyunduruk süreci”nin üstesinden gelebilmek için kendi içsel doğalarını da denetim altına almak zorunda kalmıştır. Herbert Marcuse’nin dikkat çektiği üzere; "Savaşım insan gereksinimlerine boyun eğmesi için sürekli olarak saldırılması, denetlenmesi ve sömürülmesi gereken bir doğa üzerindeki

2 Bu bakımdan, saçma terimi, yalnızca olguların özündeki anlamsızlı̆̆ değil, bu anlamsızlı̆̆ kavrayan kişinin bilincini de ifade eder; kısaca hem yeryüzünü hem de bilinçli varlık olan insanı dile getirir (Sartre 1984: 82). 
yengide doruklanır” (1998: 90). Buna göre, üzerinde egemenlik kurulmak istenen doğa, yalnızca dışsal olanı değil, insanın içsel doğasını da kapsar: “(...) Dünyaya karşı saldırgan tavır, doğa üzerindeki egemenlik böylece sonunda insanın insana egemenliğini amaçlar." (Marcuse 1998: 93).

Doğanın sadece insana yararlı olmak için yaratılmış olduğu ve insana sunduklarıyla anlam kazandığı sanısını, insanın topluma sunduğu çalışma işlevselliğiyle değer kazandığı düşüncesi izlemiştir. Buna bağlı olarak, toplumca dayatılan, insanın nihai hedefi olarak gösterilip yüceltilen mutluluk, sağlık, gönenç gibi idealler de yalnızca “işlevsel potansiyelleri”yle değer kazanmakta, başarılı sayılmakta ve özvarlığı bastırılmış bulunan birey tarafından içselleştirilmektedir. Yani, insan yaşamı büyük ölçüde rasyonalize edilerek planlanmaktadır. Varlığını sürdürmek isteyen kişinin ise, kuşatıldığı toplumsal dizgeyle uyumlu olması beklenmektedir. Birey, bu gizil tutsaklığın dışına çıkabileceği bir varolma alanından yoksundur (Horkheimer 2010: 121).

Kendini tek somut gerçeklikmiş gibi dayatan "rasyonalize edilmiş" toplumsallık, kişiyi hazır bulduğu çevreye uyum sağlamaya yönlendirirken, onun kendi benliğiyle olan uyumunun yitirilmesine neden olmaktadır. Kendi benliğinden uzaklaşıp kurulu düzenin işleyişine katkıda bulunan bir makine konumuna indirgenmek ise, Fromm'un dikkat çektiği gibi, kişiyi derinden sarsan etkenlerin başında gelmektedir. Buna göre; "Günümüzde insana en çok acı veren, yoksulluk değil, büyük bir çarkın küçük bir dişlisi, bir robot haline gelmiş olmak ve yaşamının boş ve anlamsız olmasıdır” (1996: 217). Her anlamıyla doğadan uzaklaşmış, kendi özlerini oluşturan içeriklerden "arındırılmış" kişilerin oluşturduğu toplumda, bu acıdan kaçmak mümkün değildir ${ }^{3}$.

Doğa üzerinde egemenlik kurulduktan ve yeryüzü “ussal”laştırıldıktan sonra, bireyin kendine yetebilme potansiyeli zarar görmüş, kendini tanımlayabilmek için, bir "dişli"si olduğu kurumlara gereksinim duymaya başlamıştır. Horkheimer'in belirttiği gibi; "Becerilerini koruduğu ve şirketine, derneğine ya da sendikasına sıkı sık1ya sarıldığı sürece büsbütün yokolmayacağını hissetmektedir. Böylece aklın bireysel öznesi giderek sönen (...) bir ego haline gelir." (2010: 153). Buna göre, kişinin, yukarıdan belirlenmiş eylemlerini yinelemekten başka çaresi yok gibidir; yaptıkları kendi kişiliğinden bir iz taşımamaktadır. Horkheimer'in ifadesiyle; "Bireye, doğduğu günden başlayarak, bu dünyada bir tek varolma yolu olduğu hissettirilir: Bir gün kendini gerçekleştirme umudundan vazgeçmek" (2010: 154).

Ancak bizzat kazandığı ya da başkalarına atfettiği değeri, toplumsal düzene sağlanan yarardan çıkarsayan çağımızın insanı, sahip olduğu değer özvarlığından kaynaklanmadığı, kendisine bahşedildiği için, doğrudan bağımlılığa koşullanmaktadır. Bu bağlamda, günlük yaşamda egemen olan doğrular, sıradan insanın uzlaştığı çıkarlar çerçevesinde oluşturulmakta, ortalama olandan yetkin her türlü değer ölçütü ise ya-

3 Bir bakıma, Jung’un düşünceleriyle koşut olarak, ussallığın öne çıktığı, her olayın ardında, olgusal yaşamla uyumlu mantıksal bir nedenin arandığ 1 ölçüde, gerçek yaşam deneyimi sığlaşmaktadır. Jung’un tanımıyla; "Mantığa aşırı değer verme siyasal mutlakiyete benzer. Her ikisinin egemenliğinde de birey kısırlaşır" (2013: 277). 
dsınmaktadır. Dolayısıyla, bu değer düzeneği içinde, insanların ideallerini gerçekleştirme amaçları, genellikle, pratik bir nitelik taşımadığı, maddi bir getirisi olmadığı ölçüde aşağılanmaktadır. Kişiler, genelin çıkarını koruduğu ve uyumlu olduğu ölçüde tekil yaşamlarında yükselme şansına sahip olmakta, yükselme olanaklarına göre de kendi içsel yasalarını oluşturmaktadır. Dolayısıyla, en tinsel görünen değerlerin bile ardında uzlaşımsal bir yön bulunabilir ve bu değerin doğası nihai olarak anlamsiz sayılabilir.

Algılanan evreni doğal görünümünden kazıyıp tutsaklaştırıcı bir çehreye bürüyen uzlaşımlar, kişilerde ortak korku ya da amaçların gelişmesine ön ayak olmakta, bireyleri farklı biçimde yönlendirebilecek olan içsel yasalarını, doğalarını törpülemekte ve böylece kişiliklerinin tektipleşerek uyumlanmasına hizmet etmektedir. İnsanları uyum içine sokmanın en yaygın yolu ise, onlarda "gelecek kaygısı" yaratmaktır. İnsan, saçmanın bilincine kavuşmadan önce, günlük deneyimini sürdürürken, ilk nedenini bilmediği amaçlarını, geleceğe ilişkin beklentilerini haklı çıkarmaya çalışmaktadır. Örneğini sıradan kişi, emeklilik ve çocuklarını iş sahibi yapmak gibi hedefleri anlamlı bulurken, yaşamına yön veren kendisi olmadığı halde, özgür olduğunu varsaymaktadır. Ancak Camus'nün dikkat çektiği gibi, "bir gün uyumsuzun bilinci belirdiğinde”, değer atfedilen amaçların anlamlılığına yönelik düşünceler sarsılacaktır (2011: 70). Saçmanın bilincinde kalan insan için söz konusu olan durum, 'şimdiki zaman'ların sürekli olarak birbirini izlemesidir. Uyumsuz kişi için, önündeki tek gerçek, içinde bulunduğu “oluş anı”dır, dolayısıyla yalnızca “bu an”da gerçekleşebilecek olan eylemlerinin tek hâkimi olmak istemektedir.

Gelecekle ilgili tasarılara benzer şekilde, geçmişe ilişkin düşüncelerin de insan varlığını güçten düşürerek ortalama olanla eşitleme işlevi gördüğü söylenebilir. Bu konuda Nietzsche’nin varsayımı, kalıcı bir belleği olmayan hayvanın tersine, insanın, "kendi belini büken geçmişin yükü" altında ezildiği ve üzerindeki “ağırlık”tan dolayı yaratıcı bir yaşam sürmesinin büyük ölçüde olanaksızlaştığıdır. Geçmiş, tekil kişilerde yarattığ 1 pişmanlık ve doyumsuzlukla insana ait potansiyel gücü yoğun biçimde soğurur ve bunun karşılığında kazandırdığı hiçbir şey yoktur: "Geçmiş yalnızca kurtarılmamış kalmaz, ama kurtarılmamış olarak, tüm kurtuluşa zarar vermeyi sürdürür (Akt. Marcuse, 1998: 96). Bundan dolayı, zamanın, yaşam üzerindeki egemenliği sona erdirilmedikçe, özgürlüğe ulaşmanın olanağı da kalmamaktadır. Bu düşüncenin vardığı nokta, değiştirilebilmesi söz konusu olamayacağına göre, geçmişin, süregelen yaşamı zayıf düşürmesine izin vermemek gerektiğidir.

Öyleyse, kendi doğasına uygun bir yaşam sürmek isteyen kişinin, Nietzschecianlamda "anın eşiğinde batmayı başarması” zorunludur. Bu kişi, "oluşun masumiyetini geri verecek bir öğretiye” ihtiyaç duyar ve "yaşamın anlamı”nı, geçmişte ya da gelecekte değil yalnızca deneyimlemekte olduğu yaşamın kendisinde arar (Akt. Pearson 2011: $141)^{4}$. "Geçmiş" ve "gelecek", her zaman insanın kendi varoluşuyla arasına sınırın

4 Dürüst bir eğilimle bağdaşmayan her türlü aşkın anlam gereksinimini yadsıyan ve görünür olguları dayanak noktası kabul eden Camus'nün de yaşamı değerli kılan her türlü arayışı, "içinde bulunulan an”dan devşirmeyi önerdiğini savunmak olanaklıdır. Tersi ve Yüzü kitabındaki şu ifadeleri, huzurlu bir gelecek vaadiyle şimdiki zamanda tutsaklığa koşullandırılan insanlık durumunu eleştirmek bakımından Nietzsche’nin görüşleriyle uyum 
girmesine, varoluşun gerçek doğasının yok sayılmasına neden olmaktadır. İnsanın yaşamını sürdürürken anlamlı bulduğu değerler, geçmişte ya da gelecekte, artık geride kalan bir anda ya da şu anda ulaşılamayacak bir erekte olduğu sürece, kendi özüyle arasındaki uzaklığın giderilmesi mümkün olmayacaktır.

Doğayı dışlayan ve üzerini örten her türlü kurgusal düşünceyi yadsıyan saçmanın bilinci, insanı görünür olan gerçeklikten uzaklaştıran tüm gizleyici unsurları reddetmektedir. Dayatılan uzlaşımsal prangalardan kurtulmanın yolu ise, öncelikle gerçekliği tam anlamıyla kabul etmektir. Camus'ye göre, kendini her anlamda görünür kılan en büyük gerçeklik ölümdür, insan özgürlügünü ancak ölümün karşısında elde edebilmektedir: "Gerçekten özgür olan insan, ölümü olduğu gibi kabul ederken, ölümün sonuçlarını da kabul eden kişidir” (2003a: 93).

Saçmanın insanının uyumsuz düştüğü çoğunluğun moral değerleri ise, ölümün doğal mahiyetinin üstünü "sonsuz yaşam" ve "tanrısal adalet" gibi yeryüzünde deneyimlenme olanağı bulunmayan soyut düşüncelerle örter; en büyük gerçekliği doğadışı kılar. Bu bağlamda, Nietzsche, insan doğasına aykırı olan uzlaşımsal moral yasaların, kişilerin eylemlerini biçimlendirmekte kullanıldığını vurgulamaktadır: "Doğa karşıtı ahlak, yani şimdiye dek öğretilmiş, saygı duyulmuş ve vaaz edilmiş olan hemen her ahlak, tam da yaşamın içgüdülerine karşı yönelir. (...) Tanrının krallığının başladığ yerde, yaşam sona erer" (Nietzsche 2005: 36).

Bu noktada, bir tarafta öte dünya, ölümsüzlük, tanrısallık gibi insanı sıradan yaşamına katlanmaya, toplumsallığa boyun eğmeye yönelten varsayımlar dururken, öbür tarafta da "olumsal dünyanın ve ölümün katı gerçekliği” bulunmaktadır. Buna göre, saçma duygusunun etkisine girdikten sonra kişi, vaaz edilen ölümsüz yaşama değil, kendi denetimindeki ölüme yönelecektir. Nietzsche'nin ifade ettiği gibi, tam anlamıyla yaşama duyulan arzu, aslında tek gerçeklik olan ölümle yüzleşmeyi gerektirmektedir: "Yaşam sevgisinden ötürü istemeli ölümü, özgürce, bilinçli, rastlantıya yer bırakmadan, bir baskın gibi ani değil. (...) Kişi kendini lağvederse, en saygıdeğer işi yapmış olur: bununla, adeta yaşamayı hakeder" (2005: 87). Öyleyse, bu düşünce, yaşamın gerçek anlamda değer biçiminin, onun hiçe sayılmasıyla edimselleşebileceğini savlamaktadır. Bununla birlikte, Nietzsche’nin “ölümü istemek”le önerdiği şey, intihar ya da asketik (çileci) yaşam değildir; ölümü onaylamaya ilişkin, Camus’nün Tolstoy’dan alıntıladığı düşünceler, Nietzsche’nin görüşüne tümüyle koşuttur: “Ölümün varlığı bizi ya gönüllü olarak yaşamdan vazgeçmeye ya da yaşamımızı ölümün kapıp kaçıramayacağı bir anlam verecek tarzda değiştirmeye zorunlu kılar" (2003a: 186). Saçmanın bilinci uyarınca, yeryüzünün anlamsızlıkla yüklü ve aşkın bir değerden yoksun olduğu kabul edildiğinde, sonlu yaşamı aşan bir anlam yaratma görevi yalnızca insana ait olur. Copleston'un ifade ettiği gibi; "Dünyanın Tanrı tarafından bir amaç için yaratıldığı ya da saltık İdea ya da Tinin öz-belirişi olduğu düşüncesinin reddedilişi insanı yaşama kendi istediği anlamı vermede özgür bırakır. Ve yaşamın bundan başka anlamı yoktur” (1998: 178).

içindedir: "İnsanlar her şeyi ilerideki yaşlılık üzerine kurarlar. Düzelmezlerle kuşatılmış bu yaşlılığa kendilerini savunmasız bırakan başıboşluğu vermek isterler. Küçük bir köşke çekilmek için ırgatbaşı olmak isterler. Ama bir kez yaşlılığa gömüldüler mi anlarlar bunun yanlış olduğunu (2010: 35). 
Varoluşu değerli kılmak, kişinin kendisinden beklenenler uyarınca davranmasıyla değil, insanın kendisini tanımlayan tutkularının çizdiği yönde eylemde bulunmasıyla gerçekleşir, kişi bu yolda gerekirse tek başına kalmayı, yok olmayı göze almalı, hatta kabullenmelidir. Burada söz konusu olan içsel tutkular uyarınca kendini alt etme edimi, "trajik bir varoluş"a aittir; bunun karşısında ise Nietzsche'nin betimlediği "son insan" "n kendini koruma merkezli tavrı yer almaktadır: "Son insan, mutluluğu keşfetmiş olan ve kendini korumaktan hoşnut bir insanlı̆̆ ifade eder; bundan böyle riske atılmaya veya denemelere girmeye inanmaz. Tutku veya bağlanımdan yoksundur" (Akt. Pearson 2011: 138). Bir anlamda son insan, maddi açıdan doyuma ulaşmış, kendi halinden memnun bir "hayvan" ile eşdeğerdir. ${ }^{5}$ Son insanın karşııtı olan trajik ya da Nietzscheci ifadeyle Dionysosça insanın, saçmanın bilincini taşıdığını söylemek mümkündür. Çünkü Dionysosça insan; "Şeylerin ebedi doğası hakkında bilgi edinmiş, korkutucu hakikat hakkında gerçek bilgiye sahip, artık tanrılarda bile huzur bulamayan, baktığı her yerde varoluşun anlamsızlığının yarattığı dehşeti gören kişi”dir (Akt. Berkowitz, 2003: 95). Nietzsche’nin "kast"ın en üstünde gördüğü Dionysosça insan, gerçekliği olduğu gibi görüp kavrayan insandır, gerçekliğin tüm "korkunç" ve kuşku verici yönlerini içinde taşımaktadır (Akt. Kuçuradi, 1999: 70). Ancak gerçekliği kavramakla kalmaz, onu "trajik" biçimde onaylar, "Dionysos'un hayata dediği 'evet', trajik kişinin onayıyla, 'evet'iyle aynıdır (Kuçuradi, 1999: 74)6.

Korkutucu tüm yönleriyle onayladığı yeryüzünden kaçma eğiliminde olmadığı için, trajik insanın tüm edimleri kendi benliğini yansıtmaktadır. Nietzsche'nin Ecce Homo'da belirttiği gibi Dionysosça olan, "en yabancı, en amansız sorunlarıyla bile yaşama evet deyiş"i, "en yüksek örneklerini kurban ederken kendi bereketinin mutluluğuna varan yaşama istemi”ni dile getirmektedir (2011: 56). Mutluluğun ve acının ebedi dönüşünü idrak eden Dionysosça insan, gerçekliği olumlayışının ardından, kendisini çoğunluktan ayırıp tek başına zor bir yolu benimsemektedir. Gerçekliğin karanlık ve sarsıcı niteliği, trajik kişiye, yaşamını geri dönüşü olmayan zor bir yola sokan kendini alt etme tutkusu vermektedir.

Bununla birlikte, algıların ötesinde bir varlı̆ga, bir değere duyulan gereksinim ortadan kalkmadığında ve zihinde beliren sorular düş kırıklığıyla yanıtlandığında, kendini doğruluğa adamak ile kendini ortadan kaldırmak bir olur. Albert Camus, Tersi ve Yüzü kitabında, dünyadaki anlamsızlığın, usdışılığın, yaşamın gerçek mahiyetinin bilincine varmanın sonunda, insanın kendisini hiçliğe bırakması için önemsiz bir rastlantının yeterli olabileceğini bir örnekle açıklamaktadır. Camus̉nün örneğinde, bir insan, acı çeker, sonu gelmeyen mutsuzluklara katlanır. Anlamsız bulduğu yaşamına ait sıkıntıları önemsiz görür ve yazgısını içselleştirir. Ancak bir gün sevdiği bir dostuna rastlar, dostunun konuşurken takındığı kayıtsız tavır dikkatini çeker. Bunun sonunda kendi evine varınca, dostunun umursamaz davranışlarına içerlediği için kendini öldürür (2010: 45). Böylece Camus, saçmanın bilincini taşımanın etkisiyle,

5 Bu açıdan, son insan, Jung’un ifadelerindeki “güvenli sandığı yolu seçen ölüler”e benzemektedir (2013: 272). Bir bakıma, mümkün olduğunca engellerden muaf tutulmuş, sıradan çoğunluk tarafından onaylanan etkinliklerle örülü bir evrende yaşayanlar, hiçbir şekilde benliklerini geliştirme şansı bulamaz ve tinsel yetilerinin gittikçe körelmesi sonucunda her türlü canlllık emaresinden mahrum kalırlar.

6 Bu bakımdan "Trajik" ve "Dionysosça” terimlerinin birbirlerinin yerine kullanılması rastlantı değildir. 
dünyanın derin anlamına ilişkin beklentilerin, onun basitliği karşısında yıkıma uğramaya mahkûm olduğunu ifade etmektedir. Camus'nün örneği, yeryüzündeki anlamsızlığa ilişkin Arthur Schopenhauer’in betimlemeleriyle uyum içindedir: "İnsanların çoğunun hayatına dışarıdan bakıldığında, bu hayatın nasıl hiçbir şey söylemediğine, nasıl anlamdan yoksun olduğuna gerçekten inanılamaz; içten uyulduğunda da onun nasıl boş ve farkına varılmadan akıp gittiğine inanılamaz." (Akt. Kuçuradi 2006: 55). Yaşanılan zaman, farkına varmaksızın geçerken, bu zamanın yani yaşamın sonunu getirmek de kolaylaşmaktadır.

Eğer dünya anlam verilecek bir derinlikten yoksunsa ve kişi de bulunduğu konum itibarıyla ne kendisinde ne de yeryüzünde bir derinlik bulabilecek olanağa sahipse, kendi varoluşunu haklı çıkarması güçleşecektir. Camus'nün ifade ettiği gibi, yaşamın sığlı̆̆ının neden olduğu umutsuzluk, yaşamın sonunu getirmeyi gerektirecektir. Bu durumda, anlamın yokluğu kişinin dışındaki olay ve olgularla sınırlı değildir, yaşantısını ve acılarını da kapsamaktadır. "An”lar birbirinin aynı biçimde yinelenmeyi sürdürürken, bir anlığına bu döngüselliğin sonunu getirmek, gittikçe daha ussal görünmeye başlayacaktır. Böylece saçma duygusu, kötümser, edilgin bir evredeyken kişiyi yaşamdan koparması "an”lık bir durumdur. Aniden tüm işleyişin sonu gelebilir, varlık bir anda yokluğa karışabilecek kadar değersiz görünür ve onu ortadan kaldırmak da oldukça sıradan hale gelir.

Tersi durumda, yani intihara yönelmediğinde, absürdün bilincine ulaşmış kişinin yapacağı şey, kendi varlığını duyumsayabilmek için “sonuna kadar gitmek”tir (Camus 2003a: 47). Sonuna kadar gitmek ise, hem direnmeyi hem de eylemlerini "oluruna bırakma”yı kapsamaktadır. Yeryüzünde yaşamını sürdürmeye değecek bir işaret bulamadığı için, "uyumsuz kişis” kendisi de dahil olmak üzere hiçbir şeyi tüketmekten, harcamaktan çekinmemektedir (Camus 2011: 69).

Yeryüzünün, insan varlığının nedensizliğinin, ereksizliğinin bilincine varılmasıyla güdümüne girilen saçma duygusu, kişiyi yaratımlarının bir toz parçacığından daha değerli ve kalıcı olmadığı konusunda aydınlatmaktadır. "Saçmanın insanı" ya da "uyumsuz kişi”, bir gün tüm eylemlerinin, ortaya koyduğu her şeyin yıkıma uğrayacağını, harcanacağını öngörecek bir bilgeliğe sahiptir (Camus 2011: 130). Saçma duygusuna sahip birey, bir yandan yüce anlamlar yüklenen eylem ya da olayların zamanla yokluğa karışacağını önceden sezerken, öte yandan süreklilik gösteren, ebedi gibi görülen olayların başlangıcında önemsiz etkenlerin bulunduğunu bilmektedir. $\mathrm{Bu}$ açıdan, ne ise o olmak, nasıl davranıyorsa öyle davranmaktan başka yapacak bir şeyi yoktur. Dolayısıyla saçma duygusu, düşünsel alanda kalmaya mahkûm görünen değerleri ${ }^{7}$ yadsırken, yalnızca kişinin kendi benliğiyle tutarlılığını bir değer olarak dayatmaktadır.

Uyumsuz kişi, gerçekle ve kendi benliğiyle tutarlılığını koruyabilmek için, her zaman gerçeği olumlama eğilimindedir. Kendi benliğini eylemlerinin belirleyicisi haline getirmiştir. Eylemleri rastlantısal başlangıca sahip olsa da, yazgısallığın zorunlu izini

7 Camus, bu konuyla ilişkili olarak bir mezar taşının üzerindeki “Tükenmez ümitler” yazısına dikkat çekerek, "Bereket versin, idealistler var da, her şeyi yoluna koyuyorlar” yorumunu yapmaktadır (2010: 60). 
taşımaktadır. Bu açıdan, Camus'nün vurguladığı gibi, “saçmanın insanı” çoğunluk tarafından suçlu bulunduğu durumda bile kendini masum görmektedir; tek istediği yalnızca bildiği uyarınca yaşamak, sahip olduklarıyla idare etmek, kesinlik taşımayan hiçbir şeyin yaşamına girmesine izin vermemektir (2011: 67). Böylece kendinden başka hiçbir şeye yaslanmaksızın yaşama olanağını deneyimleme tutkusuyla hareket etmektedir.

Yukarıda irdelenen yaklaşımlar doğrultusunda, saçma düşüncesi, salt kendi başına ele alındığında, cinayet dâhil her türlü yok etme eylemini aklamak üzere kullanılabilmeye elverişlidir. Bu tehlikenin ilk farkına varan, yine Albert Camus olmuştur. Camus, bu tehlikeyi önlemenin yolunu "başkaldırı"da görmüştür: "İnsan gururunun ve büyüklüğünün kendini gösterdiği yer ne teslim oluş ne de (...) kaçış değil, ama saçmanın bilincinde yaşamak ve gene de insanın üstenimde bulunması ve olanaklı en dolu biçimde yaşaması yoluyla ona başkaldırmaktır” (2011: 63). Başkaldırı, "absürd” gibi “anlamsızlık”tan yola çıkmamakta, başlıcaları özgürlük ve adalet olmak üzere, birtakım değerler ileri sürmeyi gerektirmektedir. Saçmanın bilincine varıp başkaldırmış olan kişi, hınç duygusundan uzaktır, amacı egemenlik kurmak değil, yalnızca kendi benliğini olduğu haliyle kabul ettirmektir (Camus 1975: 28). Böylece kendi sonlu varlığını kabul ettirerek iz bırakma istemi, "uyumsuz" düşüncenin vardığı son nokta olarak öne çıkmaktadır.

Başkaldırı, insanın kendiyle savaşımında yıkıcı yanının üstesinden gelmesini gerekli kılar. Bu doğrultuda, yaşamın her yanına sinmiş olan nihilist eğilimi çözme yolunda insana en büyük gücü veren yine başkaldırı olmaktadır. Bu durumda, varoluşun anlamsız ve dehşet verici yanının derin bilgisine erişmek, kişinin yaşamını sonlandırmasını gerektirmemektedir. Sartre’ın belirttiği gibi, saçma duygusu, kişiyi intihara yönlendirmediği durumda "başkaldırı" olarak dışsallaşacaktır: "Saçma insan kendi canına kıymaz: açık seçik doğrularının birinden bile vazgeçmeksizin, yarınsız, umutsuz, yanılsamasız, ayrıca yazgısına boyun eğmeksizin yaşamak ister. Saçma insan başkaldırıda doğrular kendini” (1984: 85). Saçma duygusundan doğabilecek umutsuzluğun getirebileceği eylemsizlik halinden kurtulmak ve kendi başına ele alındığında anlamdan yoksun görünen varoluşa haklılık kazandırmak, ancak başkaldırı aracılığıyla gerçekleşecektir.

\section{Saçma Kavramının Amerikan Sinemasından Örneklerle ${ }^{8}$ İrdelenmesi}

Kendi doğasına uyduğu için, toplumsal düzeni benimseyen ve koruyan kişiler tarafından dışlanan, suçlanan ve sonunda yok edilen bireyi merkeze alan önemli bir örnek, Milos Forman'ın Guguk Kuşu (One Flew over The Cuckoo’s Nest, 1975) filmidir. Filmin başkarakteri McMurphy, büyük bir suç işlediği için değil, herkesin kişiliğinden vazgeçerek kendisini koşulsuzca teslim ettiği düzeni sorguladığı ve bunun dışında kalmayı yeğlediği için tutsaklaştırılır. Örneğin, McMurphy ile ilgili yazılmış

8 Bu çalışmada, saçma kavramını incelemek için seçilmiş olan örnekler, Guguk Kuşu (One Flew Over The Cuckoo’s Nest, Yön. Milos Forman, 1975), Bir Yerde (Being There, Yön. Hal Ashby, 1979), Siyam Balı̆̆ (Rumble Fish, Yön. Francis Ford Coppola, 1983), Uyanışlar (Awakenings, Yön. Penny Marshall, 1990) ve Forrest Gump (Yön. Robert Zemeckis, 1994) filmleridir. 
raporda, onun hakkındaki suçlamalardan çok, "yerli yersiz konuşmak”, "çalışmaya yanaşmamak" gibi özelliklerine yer verilir. Burada açığa çıkarılan düşünce, toplumun çoğunlukla kişilere çalıştıkları iş ve kazandıkları para ölçüsünde değer verdiği, McMurphy gibi genel kabulleri reddeden kişileri değerlendirebilecek ölçütü ise akıl hastanesinde bulmaya çalıştığıdır. McMurphy'nin ifadeleri, "bir bitki gibi yerinde durmadığı”, kendi doğasına uygun hareket ettiği için cezalandırıldığı yönündedir. Buna bağlı olarak, filmde McMurphy'nin sağır ve dilsiz Şef Bromden'la konuşma çabasının bile engelleniyor oluşu, bir insana ruh kazandırabilecek her türlü girişimin önlendiğine işaret eder. Bir bakıma, hastanenin dışındaki, normal sayılan dünyada olduğu gibi, herkes otomatlığa koşullandırılmakta, sistemde sorun oluşturabilecek kendilerine özgü yanlarından arındırılmaya çalışılmaktadır.

$\mathrm{Bu}$ düşünceye uygun olarak, filmde insanları tek biçimliliğe yöneltmek ve eyleme geçmekten alıkoymak için her türlü yolun denendiği görülmektedir. Örneğin, bu yöntemlerden biri olarak gerçekleştirilen, terapi seanslarının amacı, hastaların iyice geçmişe gömülmelerini sağlamak, onları içinde bulundukları anın gerçekliğinden uzaklaştırmaktır. Hemşire Ratchet, hastaların geçmiş eylemlerini, toplumsal kuralları gözeterek yargılar, sıradan olanla uyuşmayan her noktayı eleştirir. Terapideki konuşmalar hiçbir yere varmaz, yalnızca hastaların sonuçsuz tartışmalarla zaman yitirmelerine neden olur. Bu sahnelerde, "normal” toplumu oluşturan kişilerin, bir yandan geçmişin yükü, öte yandan gelecek kaygısıyla oyalanmaya yönlendirilmesine ve yaşamakta oldukları andan koparılmasına gönderimde bulunulmaktadır. Konuyla ilişkili olarak, hastanenin dışındaki insanların düzene yarar sağlamayan her türlü eylemi anlamsız bulunarak küçümsenir ve kişiler dışlanmaktansa önlerine koyulan seçeneğe uyum sağlar. Filmdeki terapi seanslarında, McMurphy, geçmiş ve gelecekle ilgili tüm konuşmaların yalnızca kişileri boyunduruk altına almaya yarayan boş sözlerden ibaret olduğunun bilinciyle sıkılırken, düzenin bekçisi Ratchet gülümser.

Filmde, çoğu insanın gönüllü şekilde dışsal bir buyruk altına girmeyi kabullendiğine ilişkin bir görüyü açığa vuran önemli bir gösterge, Harding başta olmak üzere, hastanedekilerin çoğunun, hasta olmadıkları halde orada tutulması ve beyinlerinin uyuşturulmasına izin vermesidir. Bu noktada, filmde hastaneden bahsederken kullanılan institution sözcügünün hem tımarhane hem de kurum anlamına geldiğini belirtmekte yarar görülmektedir. Böylece, hastaların akıl hastanesine olan bağımlılığ ile insanların benliklerini gönüllü olarak, sorgulamaksızın egemen kurumlara teslim etmeleri arasında bir bağ kurmak olanaklı hale gelmektedir. Dolayısıyla McMurphy’nin yönelttiği; "hepiniz buranın dayanılmazlı̆̆ından yakındığınız halde dışarı çıkacak kadar yüreğiniz yok” suçlaması, yalnızca hastanenin içiyle sınırlı olmayıp insanların tümünü kapsamaktadır.

Özgürlük düşkünlüğü nedeniyle, McMurphy, sonunda hiçbir başarıya ulaşamayacak da olsa, kıstırıldığı kapandan, kapatıldığı kurumdan dişarı çıkma dürtüsünü dizginlemez ve kaçma girişimlerini örgütler. McMurphy benzeri karakterler, kaza-

9 Guguk Kuşu filminin başkarakterinin türdeşlerine Amerikan Sinemasında sıkça rastlamak mümkündür. Bu karakterler, benzer bir yazgıyı edimselleştirirler. Örneğin, gerek McMurphy, gerekse Parmaklıklar Ardında (Cool Hand Luke, yön. Stuart Rosenberg, 1967) ya da Kanl Toprak (Badlands, yön. Terrence Malick, 1973) gibi filmlerde 
namayacaklarını bildikleri bir atılımda bulunmaktan, kendilerini bağımsızlıklarına adamaktan vazgeçmez ve bir bakıma modern Sisifos'lar olarak, başarısızlığa uğradıkları her defasında yeniden denemekten, sonuna kadar karşı koymaktan alıkonulamazlar.

Örneğin, Guguk Kuşu filminde, Billy’nin ölümünün ardından hemşirenin yalnızca “yapılabilecek en iyi şeyin gündelik rutini sürdürmek olduğu”nu öğütlemesi ve hastaları ruhsuz makinelere indirgemesine tek karşı çıkan McMurphy olur. Bir anlamda, modern insanın, birçok yıkıma, ölüme, haksızlığa tanık olmasına karşın rutin yaşamını sürdürmekten, "bir bitki gibi” yaşamaktan geri durmadığı; ancak duyarlılık düzeyi yüksek kişinin, karşılaştığı haksızlıkların sonunu getirmeye, bireysel varoluşunu gerçekleştirmeye kendini adadığı ortaya koyulur. McMurphy ile aynı türden olan bu tutkulu kişiler, sonlarının yıkım olacağını bilseler de, çabalarından vazgeçmezler. Ama filmde görüldüğü üzere, çevrelerine değer katan, kendine özgü bireysel varlıklar yitip gittikten sonra, geride kalanlar gündelik eylemlerine devam eder.

Filmin sonlarında, en zor koşullar altında dahi benliğinin damgasını vurmaktan çekinmeyen McMurphy'ye lobotomi uygulanır ve çoğu kişi gibi uyumlu bir bitkiye indirgenir. Bir bakıma, otorite için tehlike teşkil ettiği düşünülen varlıklara ruhlarını veren bireysellikleri, ortalamaya uyumlu kılınmak uğruna, onlardan kazınarak al1nır. Ancak McMurphy, bir otomata dönüştürüldükten sonra, gerçek niteliğiyle yaşayabilmek, fani varlığına ait kalıcı bir iz bırakabilmek için, Şef Bromden tarafından öldürülür.

Ardından Bromden, McMurphy'nin planına uygun olarak, terapi odasındaki musluğu söker ve onu pencereye fırlatıp kaçar. Şef 'in kaçış sekansında öncelikle, ona özgürlüğü getirecek olan musluk söküldükten sonra fışkıran su, uzun süre gösterilir. Bir anlamda, özgürlüğe doğru yol alınca yaşam kaynağının açığa çıktığı ve insanın yaşayan bir ölü olmaktan kurtulduğu vurgulanır. Şef, uzun süre bağımlı kaldığı kurumun dişına çıkıp doğaya kavuştuğunda ise, onu düzene en çok uyum sağlamış olan Harding'in, teller ardından, bir esir gibi, izlediği görülür. Filmin başlarındaki terapiden hatırlanacağı üzere, Harding birtakım hayat dersleri verdiğini düşünerek bolca konuşmakta ve sözleriyle kendi edilgenliğini haklı çıkarmaktadır. Buradan yola çıkarak, filmde, kendi başına düşüncelerin ve sözlerin aslında yalnızca içi boş kavramlardan ibaret olduğu ve insanı eylemden alıkoymaktan başka işe yaramadığı şeklinde bir savın sergilendiğini düşünmek mümkündür. Dolayısıyla, kaçma işini yalnızca hiç konuşmayan Şef'in becermesi, en çok konuşan Harding'in ise tellerin arkasından gösterilmesi filmde sergilenen bu tutumu daha açık kılmaktadır.

Hal Ashby'nin yönettiği Bir Yerde (Being There, 1979) filminde ise, saçma kavramıyla ilişkilendirilecek biçimde, yaşamın özündeki yalınlık dile getirilmekte, değer verilen ve ciddiye alınan olguların altındaki basit ve rastlantısal dayanak noktaları ortaya

odaklanılan karakterlerin, toplumsal ve kurumsal her türlü boyunduruğu yadsıyıp özvarlıklarını dışsallaştırarak gerçek anlamda yaşamayı seçtikleri için, otomatlar sisteminin dışına itildiğini söylemek olanaklıdır. Bu dışlama bazen hapse atarak, bazen akıl hastanesine yollayarak, bazen de idam ederek gerçekleştirilir ve onların yazgısı, yeryüzünde dürüst ve dolayısıyla da gerçek hiçbir varlığa şans verilmediğini gösterir. 
koyulmaktadır. Filmin başkarakteri Chance, yaşamı boyunca bahçıvanlık yaptığı evin dışına çıkmamış, evrene ilişkin algısını yalnızca bu sınırlı alan ve televizyon aracıllğıyla oluşturmuştur. Chance, yaşı ilerleyene kadar, deneyim dünyasından uzak kaldığı, kendisine ilişkin hiçbir kayıt olmadığı için, doğallığını korur ve onun bazen "aptallık" gibi algılanan doğallığ $1^{10}$, rastlantısal biçimde yüksek konumlara gelmesini sağlar.

Chance, olayları, onların özünde bulunmayan anlamlar yüklemeden, oldukları şekilde algılar ve onun kavrayışı uygar dünyanın insanınınkiyle uyuşmaz. Örneğin, bahçıvanlık yaptığı ev sahibi öldüğünde ya da sonradan evine yerleştiği Benjamin Rend ölüm döşeğindeyken, en ufak bir gösterişli bir tavırda bulunmaz ve normal kabul edilen bir tepki göstermez. Belki de insan için en önemli olgu olan ölüm, Chance için, yaşamın doğal bir görüngüsünden başka bir şey değildir. Chance’in kavrayışındaki basitlik, onun tüm konuşmalarına ve davranışlarına yansır. Ancak, doğallığını yitirmiş ve bu şekilde normalleşmiş kişiler, onun tüm sözlerinde ve tutumlarında karmaşık bir yön bulmaya çalışır. Chance'in konuşmaları yalınlıklarından soyulup, yan anlamlar yüklenerek algılanır; onun yalnızca kendi dünyasının sınırlarıyla dile getirdiği düşünceler, sıradan kişilerce yüce anlamlar atfedilen birer metafora dönüşür. Örneğin, Devlet Başkanı bile onun "kesin görüşlerine hayran kaldığını ve senatoda asıl eksikliği çekilenin bu olduğunu" belirterek, topluma hitaben yaptığı konuşmada Chance'ten alıntılara yer verir. Böylece filmde, hem insanların her türlü doğallığı yadsıyıp onu muğlak bir hale getirdiği vurgulanır, hem de derin anlamlar yüklenen ifadelerin özündeki aleladelik açığa çıkarılır.

Bununla birlikte, filmdeki sıradan kişiler, gündelik yaşamlarında doğallığını koruyan herhangi bir varlıkla karşılaşma şansı bulamaz; bu şansa kavuştuklarında da, bu doğallıktan, Chance'ten kuşku duymaya, onun kökenlerini araştırmaya başlar. Ancak Chance’e ilişkin, uygar dünyaya ait, kredi kartı, kimlik belgesi, ehliyet gibi, hiçbir ize rastlayamayınca, böyle bir adamın gerçekten var olabileceğine inanmakta güçlük çekerler. Bir bakıma, kendi yapay kurumlarının yarattığı tanımlama biçimlerine, tanımlanan varlığın kendisinden daha büyük gerçeklik yüklerler. Konuyla bağlantılı olarak, çeşitli yayın kuruluşları, Chance'in adına bir kitap yazdırmayı teklif eder ve Chance'in kendisini salt bir simgeye indirger. Böylece bir bakıma, hem önem atfedilen kavramların yalnızca yüzeysellikten, görünüşten ibaret olduğu vurgulanır hem de gerçekliğin insanlar tarafından büyük ölçüde çarpıtıldığı gösterilir. Böylece, toplumsal tabakanın en küçük katmanındaki kişilerin bile bilgilerinin saklandığı ve yaşam koşullarının katı biçimde belirlendiği modern çağdaki ussallığın salt görünümden ibaret olduğu ve temelinde bir usdışlık, saçmalık barındırdığı ortaya koyulur.

Filmin doğasıyla özdeş başkarakterini en yalın biçimde kavrayabilen kişi, sonradan yerleştiği evin ölmek üzere olan sahibi Ben’dir. Yalnızca Ben "doğal olma meziyeti”ni,

$10 \mathrm{Bu}$ yönden Chance ile Budala romanının kahramanı Mişkin arasında bir bağ kurmak olanaklıdır. Romanın dürüst ve saf iyi niyete sahip yegâne kişisi olan Mişkin, uzun süre yalıtıldığı sanatoryumdan çıkıp "gerçek" yaşamın içine karıştıktan bir süre sonra, kendine özgü niteliği ve doğal yapısı nedeniyle bu dünyayla uyumsuz hale gelir (Dostoyevski,, 2013). Romanın sonunda ise olguların her yönden usdışı niteliği (Chance’ten farklı olarak) onun yeniden sanatoryuma kapatılmasını getirecektir. 
"büyük bir yetenek" olarak değerlendirir ve Chance geldiğinden beri “ölüm düşüncesinin kendisini daha az rahatsız ettiği”ni söyler. Bir bakıma, Chance'le karşılaşmasının ardından, geçici ve yüzeysel bir evrende yeniden doğayla bütünleştiğini hisseder ve ölümü doğal bir görüngü olarak benimsemeye başlar.

Ben'in cenazesi gerçekleşirken, kendisine ait sözler okunur ve geçmişte kalmış bu sözler, ölümün ardından anlamsız ses yığınlarından ibaretmiş gibi duyumsanır. Törenden sonra Ben'in tabutunu taşıyanlar, Başkan’ın kendisinin ve konuşmasının sıkıcılığından bahsederler. Bu sahnede, insan için en kati gerçek olarak ölümün kaçınılmazlığı, ölü bedenin en yakınında bulunanların bile umrunda değilmiş gibi görünür. $\mathrm{Bu}$ şekilde, en kesin gerçeklik bir kez daha en sıradan gündelik yaşam sorunları uğruna görmezden gelinir.

Yitirilen kişi, tabutunun başındakilerin bile aklında değildir. Ben’in cenazesinde tartışılan konu, bir sonraki Başkan’ın taşıması gereken niteliklerdir ve konuşmalarda başkanlık için Chance'in adı öne çıkarılır. Adayı belirleyen kişilere göre, Chance'in geçmişe ait bir kaydının olmaması, onu bir “ayak bağı”ndan özgür kılmaktadır. Böylece bu kısımda öncelikle, kişinin doğal bir varoluş sürdürebilmesinin ilk koşulu olarak, yalnızca içinde bulunulan ana değer vermenin önemi ortaya koyulur ve kişiyi tutsaklaştıran geçmiş ve geleceğe ilişkin her türlü zaman tasarımı yadsınır. Bunun yanında, sahnede asıl vurgulanan düşünce ise, her ne kadar doğaya aykırı ussallaştırma girişimleriyle düzene sokulmaya çalışılsa da, yaşamda asıl egemenlik süren olgunun rastlantı ${ }^{11}$ olduğudur. Filmin sonunda, yeni başkan olarak ismi üzerinde uzlaşılan Chance, törendeki kalabalıktan ayrılır ve göl kıyısına gelir, eğilmiş bir fidanı düzeltir. Ardından batmadan suyun üzerinde yürümeye başlar; bu sırada Başkanın ağzından Ben’e ait; "Yaşam, zihnin bir durumudur." şeklindeki sözler yinelenir. Böylece sıradan olanın bilincine göre yapılandırılmış bir yaşam kavrayışı sorgulamaya açılır ve Chance'inki gibi doğal bir algı biçiminin, tüm düşsel niteliğine karşın, olgusallaşma olanağı bulabileceği gösterilir. Bunun yanında, aynı sahnede vurgulanan önemli bir konu, Chance'in isminden hareketle, rastlantının her türlü "batma" tehlikesine karşın, yüzeyde var olmaya devam edeceğidir.

Francis Ford Coppolảnın Siyam Balı̆̆ (Rumble Fish, 1983) filminde, yine alg1 ve kavrayış yönünden normal sayılan kesime dâhil olmayan bir karaktere odaklanılır ama buradaki karakter kendisini kuşatan sınırları aşma şansı bulamaz ve sonunda sıradanlığı dayatan baskı unsurları tarafından yok edilir. Filmde, insanın rastlantısal biçimde içine firlatıldığı çevresel koşulların bireysel yaşam üzerindeki kısıtlayıcılığ1 vurgulanır. Örneğin, gökyüzünde sürekli hareket halinde olan bulut imgelerinin, yerden devamlı yükselen toz kümeleri ve dumanlarla birleşmesi, yaşanan muhite bir çeşit akvaryum görünümü kazandırarak bu kıstırılmışlık duygusunun pekiştirilmesini sağlar. Benzer şekilde, polisin, çevresiyle uyumsuz The Motorcycle Boy’a gözdağ 1 verdiği sahne başta olmak üzere, birçok bölümde belirgin bir şekilde saat imgelerinin ön plana çıkarılması, zamanın kişiyi tutsaklaştırıcı etkisini ortaya koyar.

Filmin ilerleyen bölümünde, The Motorcycle Boy’un, kendisine öykünen ve sürekli

11 Bu noktada, karakterin adının Chance olması, söz konusu düşünceyi büyük ölçüde pekiştirmektedir. 
çete kavgalarına karışan kardeşi Rusty James, gasp edilir ve başından yaralanıp yere düşer. Ardından, ruhu bir anlığına bedeninden ayrılır, bir balığın akvaryumda dolanması gibi, kendi muhitinde süzülmeye başlar ve gezintisi bitince bedenine geri döner. Bir bakıma sahnede, her türlü kuşatıcı etkenle donatılmış bir ortamda ruhların bile dizginlerinden kurtulamayacağı gösterilir ve böylece insan varoluşunun ezeli-ebedi görünen tutsaklığ vurgulanır.

Konuyla ilişkili olarak, filmde tüm yazgılarının yaşadıkları ortamın kısıtlayıcı koşulları tarafından şekillendirilmesine dayanamayan insanlar ile akvaryuma hapsedilmiş siyam balıkları arasında koşutluk bulunur. Filmin uyumsuz karakteri The Motorcycle Boy, siyam balıklarının birbirlerini öldürmemeleri için ayrı olarak akvaryuma koyulduklarını belirtir, çünkü siyam balıkları kendilerini çevreleyen cam fanusa katlanamayan bir türdür. Dolayısıyla, The Motorcycle Boy’un renk körlügüunün bir yansıması olarak, tümü siyah-beyaz çekilmiş filmde yalnızca siyam balıklarının renkli olarak gösterilmesinin anlamı, onlarla The Motorcycle Boy türündeki insanlar arasında bir bağ kurulmuş olmasıdır. Buna göre, The Motorcycle Boy ve onunla türdeş olan azınlık, kendilerini kuşatan yeryüzünün tekdüzeliğinden kaynaklanan kasvetin tümüyle ayırdındadır ve canlı renklere sahip bireysel varlıkları her gün aynı soluk görüntüyle karşılaşmaktan sıkıntı duyar ${ }^{12}$.

Normal kişiler tarafından deli damgası vurulan The Motorcycle Boy, babasına göre, yalnızca "başka bir alemdedir, yanlış zamanda ve yanlış yerde doğmuştur". Bir bakıma, rastlantısal olarak içine düştüğü evren, yazgısını biçimlendirmiştir. Çünkü başka şartlar altında bir 'deha' olarak saygı görebilecek iken, kendi seçmediği akvaryum koşullarında yalnızca 'tekinsiz bir serseri' olarak saygı uyandırabilir ve özgür varlığı sürekli dizginlenmeye çalışılır. Bunun yanında, yine babasının tanımıyla, The Motorcycle Boy “istediği her şeyi yapma yeteneğine sahip olmasına karşın, yapacak hiçbir şey bulamaz". ${ }^{13}$ Her iki karakter de, kuşatılmış oldukları tüm olgu ve olayların altındaki nihai anlamsızlığın ayırdındadır ve bundan dolayı kendilerini her türden ani eyleme bırakabilecek bir kayıtsızlığa sahiptir. Bunun sonucunda, kendilerini her türlü doyumdan mahrum biçimde sıkıştırılmış hissettikleri fanustan kurtulabilmek için Stavrogin intihar eder; The Motorcycle Boy ise kendisi ve kardeşi gibi kişileri özdeşleştirdiği siyam balıklarını nehre ulaştırmak, özgür kılmak için kendini feda eder. The Motorcycle Boy'un yarı yolda ölmesiyle, siyam balıklarının renkleri, soluk dünyanın gri tonlarına dönüşür; Rusty James onları nehre ulaştırınca yeniden eski renklerine kavuşurlar ve özgürce ilerlemeye başlarlar. Burada, bir anlamda, kişinin gerçek varoluşuyla bütünleşmesinin ancak doğal ortamda ulaşılan özgürlükle olanaklı hale geldiği vurgulanmaktadır.

12 John Carpenter’ın Yaşıyorlar (They Live, 1989) filminde, ideolojiden yalıtılmış şekilde, en yalın haliyle gerçekleri göstermeye yarayan gözlüklerin de yeryüzünü siyah-beyaz göstermesi, yine benzer bir düşünceyi dişavurur.

13 Bu sözler, Dostoyevski'nin Cinler romanının başkahramanı Stavrogin’e yönelik söylenir ve The Motorcycle Boy, etkileyiciliğiyle çevresi için bir tapınç unsuru olmak ama kendi eylemlerinde hiçbir şekilde yoğun bir haz duygusuna ulaşamamak bakımından Stavrogin’le benzeşmektedir. Konuya ilişkin olarak, Stavrogin şu sözleri örnek gösterilebilir: "Eskiden her zaman olduğu gibi, gene iyilik yapabilir, bundan haz duyabilirim. Ama aynı anda kötülük yapar, ondan da haz duyabilirim. Ne var ki, her iki haz duygusu da eskiden olduğu gibi, aşırı derecede küçüktürler. Hiçbir zaman güçlü olmuyorlar” (Dostoyevski 2006: 660). 
Filmin sonlarında, The Motorcycle Boy, siyam balıklarının ve kardeşinin özgürlüğe kavuşmasını sağlarken vurulduğunda, eskiden büyük saygı gördüğü mahalle sakinleri için yalnızca bir gösteri nesnesine dönüşür. Tanıdıkları, The Motorcycle Boy'un cansız gövdesine bakıp kendi aralarında konuşur ve sonra giderler; eski tanrıları artık yalnızca ölü bir bedenden ibarettir. Böylece sahnede, hem ölüm anında en kendine özgü kişilerin bile en hızlı şekilde yokluğa karışacakları gösterilir, hem de bu kişiler aracılığıyla "ete kemiğe bürünmüş”, değer atfedilen kavramların geçici doğası açığa çıkarılır.

Önündeki en açık gerçekleri dahi hiçleştiren sıradan insanın yaşamındaki boşluk ve anlamsızlı̆̆a dikkat çeken bir başka yapım, Uyanışlar (Awakenings, Yön. Penny Marshall, 1990) filmidir. Uyanışlar'da, Guguk Kuşu filminde olduğu gibi, zihinsel ve sinirsel yönden hastalık ya da farklılık taşıyan karakterler merkeze alınıp rahatsızlık ve düşkünlükle ilgili tanımların, yalnızca çoğunluğun içinde bulunduğu durumu normal kılmak için konulduğuna dikkat çekilir. Bu filmlerde ötekileştirilen başkarakterlerin en belirgin özelliği, doğal davranmaları, yaşamlarında çoğu kişinin benimsediği çıkarcı ve riyakâr bir tutumdan uzak olmalarıdır. Dolayısıyla, bu filmlerde, olgusal dünyada kişisel çıkar için başkalarına zarar vermek ya da ikiyüzlü bir tutumla toplumsal itibarını arttırmak gibi normal sayılan davranışları hor görenlerin hasta sayıldığına gönderimde bulunulur. Bir bakıma, bu karakterler aracılığıyla, insanların kendi doğalarına uygun davrandıkça toplumla olan uyumsuzluklarının arttığını ve bir çeşit hasta yerine koyulduklarını düşünmek olanaklıdır.

Bu bakımdan, ancak yanılsamaları içselleştiren toplumdan yalıtılmış durumdaki kişiler, insan varlığına ait gerçekleri dile getirmekte ancak haykırışlarına hiçbir karşılık verilmemektedir. Örneğin, filmin başkarakteri, ansefalit iltihabı hastası Leonard, büyük bir coşkuyla; "İnsanlar yaşıyor olmanın anlamını unutmuş, ellerindekinin ve kaybedebileceklerinin ne olduğunu onlara hatırlatmalıyı" dediğinde, en yakınındaki insanlar bile bu sözleri, hastalığın etkisine yorar ve anlamsız bulur. Ancak olgusal dünyanın etkilerinden yalıtılmış bir kişi, bir 'hasta', insanların gerçek anlamda sahip olabileceği en değerli şeyin, özvarlıklarının önlerine koyduğu bir yaşam biçimi, kendi benlikleriyle özdeşleşmiş bir yazgı olduğunu fark edebilir. Onların bilincine vardığı bu gerçekler, zihinlerini olgusallığa teslim etmiş çoğunluğun dünyasında hiçbir şey ifade etmez. Bu doğrultuda, olgusal yaşam tutsaklığının kişileri asıl amaçlarından saptırdığını ve yalnızca bir sürelik yükselme ve maddi çıkar elde etme hırsıyla kendilerini hiçliğin içine atmalarına olanak verdiğini söylemek mümkündür. Dolayısıyla, Leonard’ın “Asıl krizde olan biz değiliz, onlar” şeklindeki haykırışı, duyarlılık düzeyini yükselten bir hastalığa sahip olmayan kişilerin yaşamının bir hiç uğruna harcandığını ifade eder. Ancak çoğunluk, bu filmde de, kendi tutsaklıklarıyla yüzleşmektense, asıl sorunun ötekileştirdikleri bu farkındalık düzeyi yüksek kişiden kaynaklandığını düşünür ve onu özgürlüğünden alıkoyar.

Leonard, benzer eğilimle, Doktor Sayer’ “yalnız ve korkak” olmakla, gerçek bir hayattan mahrum olmakla, "asıl uyuyan” kişinin kendisi olduğunu fark etmemekle itham eder. Filmde yer verilen bu suçlamaların, aslında insanların geneline yöneltilmiş olduğunu düşünmek olanaklıdır. Çünkü filmde de görüldüğü üzere, çok büyük bir 
çoğunluğun, yalnızca maddi arzular uyarınca davranırken, vardığı hiçbir hedeften tam bir hoşnutluk duymadığına ve ulaşılan her arzunun yenisini doğurduğuna tanık olunmaktadır. Buna bağlı olarak, normal kişilerin evreninde değer verilen yaşam biçimi, yalnızca hiçbir amaca varmayan bir sürüklenişten ibaret görünmektedir.

$\mathrm{Bu}$ noktadan hareketle, filme adını veren asıl uyanışın, Doktor Sayer ve Leonard'ın annesi tarafından yaşandığını düşünmek mümkündür. Örneğin, Leonard'ın hastalığı yeniden güç kazandığında, annesinin; "Oğlum sağlıklı doğduğunda nedenini sormadım, bu mükemmel çocuğu hak etmiş miydim? Ancak hastalandığında nedenini sordum" şeklindeki sözleri, insanların genelinin yazgısının, yaşamlarını bitmek bilmeyen arzular peşinde tüketmekten, daimi bir mutsuzluğa saplanmaktan ve sahip olduklarının değerini ancak kaybedince anlamaktan ibaret olduğunu vurgular. Bununla birlikte, günlük yaşamda sıklıkla yinelendiği gibi, insanın ulaştığı bu farkındalık durumu ve gerçek anlamda uyanış, genellikle yaşamın bütününü kuşatmaz. Dolayısıyla filmde, ölü gibi yaşadığı ve yaşamlarında yalnızca bir anlığına uyanış, ayıklık ya da açık bilinçlilik durumuna geçtiği belirtilen kişilerin, hastalardan ziyade siradan çoğunluk olduğu sonucuna ulaşmak mümkündür.

Forrest Gump (Yön. Robert Zemeckis, 1994) filminde, yine zihinsel farklılığıla öne çıkan bir başkaraktere yer verilir ${ }^{14}$. Filmin başkarakteri Forrest'in zeka düzeyi ortalamanın altındadır ve bundan dolayı duyduğu her sözü ya da gördüğü her şeyi yalnızca oldukları gibi algılar. Forrest’in dolaysız algılama biçimi aracılığıly, filmde, normal kişilerin deneyimledikleri olgu ve olayların altında, genellikle bunların barındırmadığı zorunlu bir neden ya da yüce bir anlam aradığına dikkat çekilir. Örneğin, filmde insanların beğenisini kazanmış bir dans figürü, bir slogan ya da bir şarkının kaynağında aslında normal kişiler tarafından aşağılanan düşük zekâ düzeyine sahip birinin payı olduğu görülür. Bir anlamda, bu şekilde, değer atfedilen olgu ve olayların, aslında oldukça bayağı ve rastlantısal bir nedenden kaynaklandığ 1 vurgulanır.

Benzer şekilde, filmde insanların geçmişte kalmış, atalarına ya da kendilerine ait edimlerden yola çıkarak, kendi yaşamlarına ilişkin uslamlamalara giriştiğine, ancak yaşantılarının bu ussallıkla uyuşmadığına dikkat çekilir. Bununla birlikte, Forrest, yaşamı hiçbir akıl yürütmeyle uyumlu kılmaya, ona sahip olmadığı anlamlar yüklemeye girişmez ve her deneyimi oldukları biçimiyle kabullenir. Örneğin, yakın arkadaşı Bubba, yaralı bir şekilde ölmek üzereyken, bunun "neden” gerçekleştiğini sorar; çünkü karides gemisi kaptanı olma hayali vardır ve bu hayale ulaşamadan ölmesi saçma görünmektedir. Bunun karşılığında Forrest, Bubba’ya, yalnızca, vurulduğunu söyler. Bu yanıt, yaşamın hiçbir hayale aldırmadan ilerlediğini gösterir; bir anlamda, insan, geleceğine ilişkin birçok plan yapsa da, aniden vücuda saplanan bir kurşun tüm planları ve düşleri anlamsız kılar. Benzer şekilde, Forrest, Teğmen’i kurtarıp, ba-

14 Forrest Gump ile Bir Yerde filmlerinin başkarakteri toplumda kabul gören değerlerin farkında olmamaları, bu konulara tümüyle ilgisiz olmaları yönünden benzeşmektedir. Karakterlerin bu durumu, onların yalnızca kendi zihinlerine dayanmalarının yolunu açar ve rastlantıya kolaylıkla uyum sağlayarak kendilerini gerçekleştirmelerine ön ayak olur. Böylece, saçma duygusunu taşımıyor olsalar bile yeryüzünde hüküm süren “saçma” lığı betimlemenin bir aracı haline gelirler. 
cakları kesilecek de olsa, yaşamasını sağladığında Teğmen buna sinirlenir. Teğmen’e göre: "Herkesin bir kaderi vardır, hiçbir şey öylesine olmaz. Hepsi planın parçasıdır"; atalarından miras aldığı yazgısı, onun savaş alanında ölmesini gerektirirken şimdi "bacakları olmayan, sakat bir ucube"ye dönmüştür. Teğmen’in sözleri, bir kez daha, yeryüzü yaşamına bir nedensellik atfederek onu ussallaştırma çabasını yansıtır; ancak karşılaşılan yanıtlar hiçbir zaman hiçbir zaman usa uygun nitelikte değildir. Dolayısıyla, filmde bunu kavrayabilme yetisi yalnızca ussal yönden gelişmemiş kabul edilen birine aittir. Bu doğrultuda, Forrest, yaşamın önüne çıkardığı mantıksal ya da mantık dışı olarak yorumlanabilecek, her rastlantıyı oldukları biçimiyle kabullendiği ve bu rastlantısallığa kolaylıkla uyum sağlayabildiği için, gittikçe daha yüksek konumlara gelir; yaşam, gelişigüzel biçimde gerçekleşen yazgısallığa "boyun eğen” bu kişiyi ödüllendirir.

Bunun yanında, rastlantıların yardımıyla, Forrest her ne kadar iyi bir yaşam sürmeye başlamış olsa da, kazandığı itibara değer vermez; çevresindeki kişiler, onun elde ettiklerini, eylemlerini daha çok önemser. Örneğin, Forrest, televizyona çıktığında, konuşma yaptığında ya da birtakım başarılar kazandığında kendi eylemlerinin sıradanlığının, gelip geçiciliğinin farkındadır; bundan dolayı kendine ait görüntüleri bile izlemez. Bu edimlere, taşımadığı anlamları yükleyen çoğunluk, Forrest'in eylemleriyle daha ilgili görünür ve eskiden küçümsedikleri bu kişinin en büyük destekçisi olmaya başlar. Böylece bir bakıma, yeryüzünde değer kazanmış olguların tümüyle olumsallık ve rastlantısallık taşıyan niteliği açığa çıkarılır.

Konuyla bağlantılı olarak, sevgilisi gittiğinde, Forrest, nedensiz yere koşmaya başlar, önce kasabayı, sonra eyalet sınırını aşar ve okyanusu koşarak geçmeye karar verir. İnsanlar, Forrest'in koşusunun altında bir neden arar, bunun amaçsız yapılabileceğine inanmazlar ve böylece onun arkasındaki kalabalık her geçen gün çoğalır. Yaklaşık üç yıl koştuktan sonra bir gün durur ve "canı istediği için" başladığı koşu, "yorulduğu için" biter. Nedensiz başlayıp aynı nedensizlikle son bulan bir eylemin peşine takılmış kalabalık ise bu noktadan sonra "ne yapacaklarını" bilemez. Böylece bir anlamda, filmde, evrendeki olayların nedensizliğini kabullenmek ve bilinçsizce de olsa, özvarlığı bu kendiliğindenliğe adayabilmek yüceltilir. Buna bağlı olarak, filmin başlangıcında Forrest' in ayakucuna savrularak düşen tüyü, kitabının arasına koyması ve filmin sonunda aynı tüyün rüzgâra kapılarak havada süzülmesine izin vermesi, yine varoluşun rastlantısal yazgısının onaylandığını ve her varlığın bu kendiliğindenlik deneyimine atılmasının olumlandığını gösterir.

\section{Sonuç}

Saçma kavramının ortaya çıkmasının, insanın en büyük gereksinimlerinden biriyle, üzerinde yaşadığı dünyayı anlamlandırma çabasıyla ilişkili olduğu görülmektedir. İçinde bulunulan koşullarda, kişilerin genellikle nedensizliğin hüküm sürdügü olgularla ve anlamsızlıkla damgalanmış alışkanlıklarla örülü bir evrene yazgılı olması, saçma duygusunun temel nedeni olarak öne çıkmaktadır. Bir anlamda, insanın yeryüzünün derin bilgisine ulaşmaya çalışırken, olguların sı̆̆ ve bayağı yanıtlarıyla karşılaşıyor olması, varoluşun saçma niteliğinin bilincine erişmesini hazırlamaktadır. 
Saçma kavramı yörüngesinde gelişen düşünceler, anlamsızlık algısından kaynaklanan boşluğun genişlemesini, yaşamı katlanılır kılacak bir değerin çıkarsanabileceği doğanın araçsallaştırılması, denetim altına alınması ile ilişkilendirmektedir. Buna göre, bir bakıma, insanı çevreleyen dışsal doğanın araçsallaştırılması, sonunda insanın içsel doğasının, özvarlığının tutsaklaştırılmasını getirmiştir. Buna bağlı olarak, çoğunluğu oluşturanlar, kendilerine ait gizilgücü açı̆̆a çıkarmaktan caydırılmakta, dışsal olarak belirlenen gereksinimler uyarınca, yalnızca kendilerine izin verilen eylemleri gerçekleştirmeye koşullandırılmaktadır. Dolayısıyla, yaşamda yol gösterici sayılan "kutsal”lar bile, yalnızca genele ait çıkarı yansıttığı ölçüde benimsenmektedir. Öyleyse, benimsenmiş en tinsel değerlerin ardında genellikle uzlaşıma dayalı ve nihai olarak anlamsız bir temel bulmak mümkündür.

Buna bağlı olarak, evrenin özüne işlemiş saçmalığa odaklanan düşüncelerde, her zaman için, yalnızca şimdi ve burada olana, en yalın anlamıla gerçekliğe önem verilmekte; gerçekliğin en katı biçimine ise ölüm olgusunda rastlanabileceği savlanmaktadır. Bu doğrultuda, saçmanın bilinci, ölüm nedeniyle tümüyle hiçliğe gömülmekten kurtulmak, geçici yaşama kalıcılık kazandırmak için, kişiyi ölüm tehlikesini göze almaya yönlendirmektedir. Dolayısıyla, saçmanın idrak edilmesi, aniden can sıkıntısına dönüşebilen, onaylanmış, yanılsamalı bir mutluluktansa, her türlü acının göğüslenmesini gerektiren bireysel adanış durumunu daha yeğlenir kılmaktadır. Bu noktada, gerçekliği tüm karanlık yönleriyle benimsemiş, saçma duygusuna sahip kişiyi karamsar bir edilgenliğe gömülmekten kurtaran, bireysel varlığına haklılık kazandıran adanış eylemi başkaldırı olmaktadır.

Saçma kavramının merkezi bir konum teşkil ettiği Amerikan sinemasına ait film örneklerinde, başkarakterler, rutin bir yaşam sürdüren otomatlar olmaktan sıkıntı duymakta ve uzun bir süre bir köle gibi yaşayıp yokluğa karışmaktansa, zamanın yıpratamayacağı, kendilerine ait bir iz bırakma tutkusuyla ölüme meydan okumaktadır. Böylece, özellikle, her türlü anlamlandırma çabasını boşa çıkaracak, insan yapıntısı bir düzeneğin dişlisi olarak, ortalama ve uysal bir yaşam sürdürmek yerine, özvarlıklarından kaynaklanan bir içtepiyle kendilerini ortaya koymaya ve genellikle başkaldırmaya yönelmektedir. Söz konusu karakterler, kendilerini kuşatan zorunluluklar ağının dışına çıkmak amacıyla, kolaylıkla alelade olayların boyunduruğuna girmekte ve içine savruldukları rastlantısal olaylar dizisi onların zorunlu yazgısını oluşturmaktadir.

Dolayısıyla yaşamlarını nasıl sürdüreceklerini şekillendiren düzeneğin her türlü ussal dayanaktan yoksun olduğunu fark etmeleri, bu karakterlerin, Nietzsche'nin görüşleriyle uyumlu olarak, yaşamlarını dayandıracakları yasayı kendilerinden devşirmelerine zemin hazırlamaktadır. Bu yasa ise, karakterlerin doğalarını, zorunlu yanlarını ortaya koymalarıyla dışsallaşır. Bir bakıma, Camus'nün Nietzsche üzerine değerlendirmelerinde rastlanacağı gibi, gerçek anlamda zorunlu olanı onaylamak, özgürlüğe yönelmiş başkaldırının birincil şartı haline gelmektedir. Bu açıdan, söz konusu filmlerde, rastlantısallık ve yazgısallık, özgürlük ve zorunluluk gibi karşıt görünen kavramların taşıdığı birlik, dışsal belirlenimlerden uzak duran bireysel varlıkların kişiliğinde somutlaştırılmaktadır. 
İncelenen filmlerde yoğunlaşılan karakterler, kurmaca bir işleyişe tüm varlıklarını teslim etmiş olan çoğunluğun onayladığı, itaatkâr yaşam biçimini sürdürmektense, yalnızca doğal olandan, kendi doğalarından kaynaklanan güdülerle karşı koymayı seçmektedir. Bunun sonucunda ise, öngörülebilir işleyişten sıkılmış olan bu karakterler, eylemleriyle genellikle rastlantısal olayların güdümüne girmekte ve bu ilineksel varoluş biçimi, zorunlu bir yazgıyı hazırlamaktadır. Onların, salt kendi çabalarıyla oluşturduğu bu yazgı uyarınca, kaybetmenin kaçınılmaz olduğu bir savaşıma, özvarlığın harcandığı bir başkaldırı edimine yöneldiğini söylemek mümkündür. Bununla birlikte, bu filmlerde, dişsal belirlenime kendini teslim etmeyi reddetme ve kendine yalnızca niceliksel bakımdan bir değer biçilmesine karşı koyma dürtüsünün, genellikle zihinsel bakımdan ayrıma tabi tutulan özelliklerle ilişkilendirildiği göze çarpmaktadır.

Bir bakıma, gerçek anlamıyla yaşayabilmek için, rahatlık sağlayan kontrollü ve makinemsi bir eylem dizgesine hapsolmayı reddetmek gerekmekte ve beraberinde sürekli huzursuzluğu getirecek bu yadsıma yetisi, ancak zihinsel yönden farklı kişilere bahşedilmektedir. Zihinsel uyumsuzluk, Bir Yerde ve Forrest Gump gibi, başkarakterin yalnızca kendini rastlantıya bırakmakla yetindiği örneklerde ödüllendirilmekteyken, Guguk Kuşu, Siyam Balığı, Uyanışlar örneklerinde, kınanmakta, kovuşturulmaya uğramakta ve en ağır biçimde mahkûm edilmektedir. Bu karakterlerin, kendilerine özgü niteliklerini ortaya koyma istençleri katılaştığı ölçüde, onlara uygulanan yaptırım ve verilen ceza daha şiddetli hale gelmektedir. Uyumsuz kişilerin cezasının şiddetlenmesine neden olan etken, onların kendi doğalarından kaynaklanan eylemleri ortaya koyma isteklerini dizginleyememesidir. Bununla birlikte, onların bu "günah"ı en ağır biçimde karşılı̆̆ını bulup her şeylerini yitirmelerine neden olsa dahi, bu karakterler saltık anlamda yenilmiş biçimde betimlenmemektedir. Onlar, içsel doğalarıyla uyum sağladıklarında, zorunlu bir şekilde başkaldırıya yönelmekte ve dışsal dünya ile uyumsuzlukları artmaktadır. Ancak, bu kişiler, uyumsuzluklarından dolayı ağır biçimde cezalandırıldıklarında, hatta yok edildiklerinde dahi, nihai bir yenilgiye uğramamakta, sonlu evrende kalıcı bir iz bırakma ayrıcalığına erişen türün tek üyeleri olmaktadır.

\section{Kaynakça}

Adorno T. ve Horkheimer, M. (2010). Aydinlanmanın Diyalektiği, Çev. Nihat Ülner, Elif Öztarhan Karadoğan, İstanbul: Kabalcı Yayınevi.

Berkovitz, P. (2003). Nietzsche: Bir Ahlak Karşıtının Etiği, Çev. Ertürk Demirel, İstanbul: Ayrıntı Yayınları.

Camus, A. (1975). Başkaldıran İnsan, Çev. Tahsin Yücel, Ankara: Bilgi Yayınevi.

Camus, A. (2003a). Defterler 1, Çev. Ümit Moran Altan, İstanbul: İthaki Yayınları.

Camus, A. (2003b). Defterler 2, Çev. Ümit Moran Altan, İstanbul, İthaki Yayınları.

Camus, A. (2010). Tersi ve Yüzü, Çev. Tahsin Yücel, İstanbul: Can Yayınları.

Camus, A. (2011). Sisifos Söyleni, Çev. Tahsin Yücel, İstanbul: Can Yayınları.

Dostoyevski F. (2006). Cinler, Çev. Ergin Altay, İstanbul: İletişim Yayınları. 
Dostoyevski F. (2013). Budala, Çev. Mazlum Beyhan, İstanbul: İletişim Yayınları. Fromm, E. (1996). Özgürlükten Kaçış, Çev. Şemsa Yeğin, İstanbul: Payel Yayınları. Homeros (2000). Odysseia, Çev. Azra Erhat, A. Kadir, İstanbul: Can Yayınları.

Horkheimer, M. (2010). Akıl Tutulması, Çev. Orhan Koçak, İstanbul: Metis Yayınevi. Jung, C. (2013). Anılar, Düşler, Düşünceler, Çev. İris Kantemir, İstanbul: Can Yayınları. Kuçuradi, İ. (1999). Nietzsche ve İnsan, Ankara: Türkiye Felsefe Kurumu.

Kuçuradi, İ. (2006). Schopenhauer ve İnsan, Ankara: Türkiye Felsefe Kurumu.

Marcuse, H. (1998). Eros ve Uygarlk, Çev. Aziz Yardımlı, İstanbul: İdea Yayınevi.

Nietzsche, F. (2005). Putların Batışı, Çev. Mustafa Tüzel, İstanbul: İthaki Yayınları.

Nietzsche, F. (2008). Deccal, Çev. Oruç Aruoba, İstanbul: İthaki Yayınları.

Nietzsche, F. (2011). Ecce Homo, Çev. Can Alkor, İstanbul: Türkiye İş Bankası Kültür Yayınları.

Pearson, K. A. (2011). Kusursuz Nihilist, Çev. Cem Soydemir, İstanbul: Ayrıntı Yayınlar1.

Sartre, J. P. (1984). Yazınsal Denemeler, Çev. Bertan Onaran, İstanbul: Payel Yayınları. 


\title{
"Absurd" as a Describer of a Reality Belonging to Existence and Its Expression in American Cinema
}

\author{
ÇAĞDAŞ EMRAH ÇAĞLIYAN
}

\begin{abstract}
One of the leading problems in human existence is whether living is a meaningful act or not. On one hand, the lack of a sound basis of the phenomena encountered in daily life and routine actions which are repeated every day, and on the other hand, the solid reality of death which confronts human existence with their temporary content, urges people to question their existence. The intersection of the effort of individual for finding a just ground for the world of existence with the negative answer of phenomena is the basis of the concept "nonsense" of Albert Camus. The concept of "nonsense" first emphasises the reasonless nature of the world, and the effort for seeking a meaning in compliance with reason in the world of nonsenses of man. This quest for meaning brings about the prosiness of all reality other than death; thus, describes a general condition of humanity. Therefore, since ancient ages, in all kinds of narrations so far, the concept of nonsense took its place as one of the basic motives. In this paper is centred on the opinions of such philosophers as Albert Camus and Friedrich Nietzsche in terms of the concept of "nonsense" and five movies chosen from American cinema with purposeful sampling method were subjected to qualitative analysis. Their means for overcoming the depression caused by meaningless and the final destiny caused by the conscious of nonsense have been examined by means of these movies.
\end{abstract}

Keywords: Absurd, Coincidence, Destiny, Albert Camus, Friedrich Nietzsche, American cinema. 